\title{
PENYULUHAN HUKUM TENTANG MERUGIKAN KEUANGAN NEGARA KEPADA KEPALA DESA SE KECAMATAN PEMAYUNG KABUPATEN BATANG HARI GUNA PENCEGAHAN KORUPSI PADA PEMERINTAHAN DESA
}

\author{
Sahuri Lasmadi dan Elly Sudarti \\ Dosen Fakultas Hukum Universitas Jambi \\ Kampus Pinang-Masak, Mendalo Indah 36361 \\ Email: slasmadi@unja.ac.id; elly.sudarti@yahoo.com
}

Kegiatan pengabdian ini dilatarbelakangi maraknya perilaku korupsi yang berkaitan dengan kerugian keuangan negara yang dilakukan oleh Penyelenggara Negara. Kepala Desa adalah pemegang kekuasaan penyelenggaraan pemerintahan desa. Permasalahannya adalah masih kurangnya tingkat pengetahuan dan pemahaman mitra terhadap UU Pemberantasan Tindak Pidana Korupsi; dan Perda Kab. Batang Hari Tentang Pengelolaan Keuangan Desa; dan akibat-akibat hukum jika terjadi penyalahgunaan pengelolaan keuangan desa. Kegiatan pengabdian ini bertujuan untuk: (1). Meningkatkan pengetahuan dan pemahaman mitra Kepala Desa beserta Perangkat Desa tentang UU Pemberantasan Tindak Pidana Korupsi dan Perda Kabupaten Batang Hari tentang pengelolaan keuangan desa; (2). Meningkatkan kemampuan mitra dalam menyampaikan ide pemikiran kegiatan terkait dengan pencegahan tindak pidana korupsi pada pemerintahan desa. Metode yang digunakan adalah metode partisipatif diharapkan mitra dapat berperan aktif dalam kegiatan penyuluhan hukum dalam bentuk (1) Ceramah Sosialisasi UU Pemberantasan Tindak Pidana Korupsi; dan Perda Kabupaten Batang Hari tentang Pengelolaan Keuangan Desa; (2) Penyuluhan hukum tentang isi UU Pemberantasan Tindak Pidana Korupsi; dan Perda Kabupaten Batang Hari tentang Pengelolaan Keuangan Desa dan akibat-akibat hukum jika terjadi penyalahgunaan pengelolaan keuangan desa. Kesimpulan: Hasil kegiatan pengabdian menunjukkan bahwa akseptabilitas yakni tingkat penyerapan mitra terhadap kegiatan mengalami peningkatan yang diukur dari tingkat pengetahuan dan pemahaman tentang materi kegiatan, yaitu adanya peningkatan pengetahuan dan pemahaman peserta tentang isi Undang-Undang Nomor 31 Tahun 1999 jo UU No 20 Tahun 2001 Tentang Pemberantasan Tindak Pidana Korupsi, Peraturan Daerah Nomor 11 Tahun 2012 Tentang Pengelolaan Keuangan Desa. serta mampu menyampaikan ide atau pemikiran berkaitan dengan pencegahan secara dini tindak pidana korupsi di kalangan Perangkat Desa. Saran: Kegiatan penyuluhan sangat bermanfaat bagi masyarakat, khususnya Perangkat Desa tentang masalah korupsi. Kegiatan penyuluhan dapat dilakukan secara berkelanjutan dan terencana.

\section{Kata Kunci: Tindak Pidana Korupsi, Merugikan Keuangan Negara, Aparat Pemerintah Desa}

\section{PENDAHULUAN}

\section{Analisis Situasi}

Pembangunan daerah merupakan bagian yang tidak bisa terpisahkan dari pembangunan nasional. Salah satu faktor penting yang sangat menentukan keberhasilan pembangunan di daerah adalah adanya dukungan dana untuk membiayai kegiatan pembangunan. Proses pembangunan tersebut menentukan kemajuan atau kemunduran dari suatu bangsa, tergantung pada tercapai tidaknya tujuan dari pembangunan tersebut. Bertambah besar volume pembangunan bertambah besar pula kemungkinan kebocoran (Evi Hartati, 2). Tindak pidana 
korupsi dikatagorikan sebagai tindak pidana yang berdampak luar biasa. Ancaman yang ditimbulkan oleh tindak pidana korupsi terhadap stabilitas dan keamanan masyakat yang merusak lembaga-lembaga dan nilai-nilai demokrasi, nilai-nilai ekonomi dan keadilan serta mengacaukan pembangunan yang berkelanjutan dan penegakan hukum (Kristian \& Yopi, 2015). Tindak pidana korupsi terdiri atas 7 (tujuh) pengelompokan, yaitu korupsi yang terkait dengan: (1) kerugian keuangan negara; (2) suap-menyuap; (3) penggelapan dalam jabatan; (4) perbuatan pemerasan; (5) perbuatan curang; (6) benturan kepentingan dalam jabatan; (7) Gratifikasi. (KPK, 2006).

Sehubungan dengan tindak pidana korupsi sebagai kejahatan kerah putih, (Harkristuti Harkrisnowo, 2002) menyatakan: bahwa pelaku tindak pidana korupsi bukan orang sembarangan, karena mereka mempunyai akses untuk melakukan tindak pidana korupsi tersebut dengan menyalahgunakan kewenangan, kesempatan atau sarana yang ada padanya. Tindak pidana korupsi yang selama ini terjadi secara meluas, tidak hanya merugikan keuangan negara, tetapi juga telah merupakan pelanggaran terhadap hak-hak sosial dan ekonomi masyarakat secara luas sehingga tindak pidana korupsi perlu digolongkan sebagai kejahatan yang pemberantasannya harus dilakukan secara luar biasa (Bambang Wijayanto, 2007). Terkait dengan tindak pidana korupsi, Indonesia masuk ranking ke 114 dari 177 daftar negara terkorup di dunia. Data itu dirilis situs Transparency International (TI) pada tahun 2013. Dalam daftar itu, negara terkorup di dunia adalah Somalia dengan skor 8. Adapun Indonesia yang berada di ranking 114 negara terkorup dengan skor 32. Berdasarkan data Transparency International yang menggunakan survei untuk menilai persepsi korupsi di 177 negara, tergambar bahwa lebih dari dua pertiga dari 177 negara dengan nilai indeks atau skor pada 2013 di bawah 50, pada skala dari 0 dianggap sangat korup sampai 100 dianggap sangat bersih (Kristian \& Yopi, 2015).

Kasus korupsi di Provinsi Jambi terkait kerugian keuangan negara Pasal 2 dan Pasal 3 UU Nomor 31 Tahun 1999. Pada tahun 2012 terdapat sebanyak 49 kasus, rata-rata pidana yang dijatuhkan 1 tahun sampai dengan 6 tahun (Pengadilan TIPIKOR Jambi, 2013).

Kecamatan Pemayung Kab. Batanghari merupakan mitra pengusul dalam Program Ipteks bagi Masyarakat yang dapat diberdayakan dalam upaya pencegahan tindak pidana korupsi pengelolaan keuangan desa pada pemerintahan desa. Kecamatan Pemayung Kab. Batanghari terdiri atas 18 desa/kelurahan. Jumlah penduduk 33.303 jiwa dengan jumlah Kepala Keluarga sebanyak 9104 KK. Jarak Kantor Kecamatan ke ibu Kota Kabupaten 25,5 km serta jarak Kecamatan Pemayung ke ibu Kota Provinsi Jambi 38 km. (BPS Kab. Batanghari, 2015).

Kepala Desa adalah jabatan yang di dalamnya melekat kewenangan dan kekuasaan. Lord Acton pernah mengatakan bahwa: "kekuasaan cenderung untuk korupsi dan kekuasaan yang absolut cenderung melakukan korupsi secara absolut pula" (Mochtar Lubis \& James C, 1995: 2). Berangkat dari pernyataan Lord Acton, dapat ditarik sebuah kesimpulan dimana kekuasaan sangat rentan terhadap tindak pidana korupsi.

Setiap kekuasaan selalu mengandung potensi disalahgunakan atau dilaksanakan sewenangwenang atau dilaksanakan dengan melampaui wewenang, hal ini dapat terjadi karena dua hal (Kristian \& Yopi, 2015: 25), yaitu: (1). Kekuasaan mengandung hak dan wewenang; (2). Hak dan wewenang memberikan posisi lebih jika dibandingkan dengan subyek yang dituntut atau 
pencari keadilan. Sebagai upaya pencegahan tindak pidana korupsi pada pemerintahan desa Pemerintah Kabupaten telah memberlakukan Peraturan Daerah Kabupaten Batanghari Nomor 11 Tahun 2012 Tentang Pengelolaan Keuangan Desa. Di dalam penjelasannya dinyatakan bahwa peraturan daerah ini memuat kebijakan terkait dengan: (1). Perencanaan dan Penganggaran; (2). Pelaksanaan Penatausahaan Keuangan Desa; (3). Pertanggungjawaban Keuangan Desa (Perda Kab. Batanghari, 2012).

Pengelolaan keuangan desa secara efektif dan efisien melalui tata kelola pemerintahan yang baik memiliki tiga pilar utama yaitu transparansi, akuntabilitas dan partisipatif.

Kegiatan pengabdian masyarakat ini dianggap sangat relevan untuk mendukung program pemerintah dalam rangka pemahaman UU Nomor 31 Tahun 1999 Tentang Pemberantasan Tindak Pidana Korupsi dan Perda Kab. Batanghari Nomor 11 Tahun 2012 Tentang Pengelolaan Keuangan Desa, kegiatan ini banyak dilakukan sharing dan diskusi dengan para ahli dan mitra sasaran untuk lebih memahami muatan isi UU Pemberantasan Tindak Pidana Korupsi dan Perda Kab. Batanghari, serta menentukan kebijakan serta langkah-langkah strategis dalam usaha mengantisipasi terjadinya tindak pidana korupsi pada pemerintahan desa.

\section{Permasalahan Mitra}

Tindak pidana korupsi adalah perilaku yang menyimpang dari kewajiban formal suatu jabatan publik, karena kehendak untuk memperoleh keuntungan ekonomis atau status bagi diri sendiri atau keluarga dekat. Berikut ini data tindak pidana korupsi pada Kepolisian Resort (POLRES) Kabupaten Batanghari Tahun 2014 - Mei 2016.

Tabel 1. Data Jumlah Tindak Pidana Korupsi di POLRES Kabupaten Batanghari Tahun 2014 - Mei 2016

\begin{tabular}{|c|c|c|c|}
\hline NO & TAHUN & PASAL YANG DILANGGAR & JUMLAH \\
\hline 1 & 2014 & $\begin{array}{l}\text { Pasal } 2 \text { ayat (1) jo Pasal } 3 \\
\text { UU No } 31 \text { Tahun } 1999 \text { jo UU No } 20 \text { Tahun } 2001\end{array}$ & 6 \\
\hline 2 & 2015 & $\begin{array}{l}\text { Pasal } 2 \text { ayat (1) jo Pasal } 3 \\
\text { UU No } 31 \text { Tahun } 1999 \text { jo UU No } 20 \text { Tahun } 2001\end{array}$ & 1 \\
\hline 3 & 2016 & $\begin{array}{l}\text { Pasal } 2 \text { ayat (1) jo Pasal } 3 \\
\text { UU No } 31 \text { Tahun } 1999 \text { jo UU No } 20 \text { Tahun } 2001\end{array}$ & 1 \\
\hline & & JUMLAH & 7 \\
\hline
\end{tabular}

Dari gambaran data pada Tabel 1 menunjukkan tahun 2014 terdapat 6 kasus korupsi yang dilaporkan ke Polres. Batanghari pasal yang dilanggar adalah menyangkut keuangan negara Pasal 2 dan Pasal 3 UU Nomor 31 Tahun 1999 dan satu kasus jo Pasal 55 KUHP. 5 (lima) orang pelaku termasuk dalam lingkup PNS pada Pemerintah Kab. Batanghari dengan jabatan: (1) sebagai Kepala BKD Kab. Batanghari; (2) Pejabat Pelaksana Teknis Kegiatan (PPTK) Pada SKPD Setda Kab. Batanghari; (3) Bendahara Pengeluaran SKPD Setda Kab. Batanghari; (4) Kuasa Pengguna Anggaran (KPA) Tahun Anggaran 2008-2010 SKPD Setda Kab. Batanghari; (5) Pengguna Anggaran (KPA) SKPD Setda Kabupaten Batanghari; dan 1 
orang penerima aliran dana anggaran makanan dan minuman SKPD Setda Kab. Batanghari Tahun Anggaran 2008-2010 melalui organisasi BKMT. Tahun 2015 terdapat 1 kasus pelaku adalah Kepala Desa, tindak pidana yang dilakukan adalah korupsi pada pengelolaan Sumber Pendapatan Desa (PAD) Desa Rantau Kapas Tuo Kec. Muara Tembesi Kab. Batanghari Tahun Anggaran 2015, pasal yang dilanggar adalah Pasal 2 jo Pasal 3. Tahun 2016 masih dalam proses, terdapat 1 kasus. Tindak pidana yang dilakukan adalah korupsi pada pengelolaan/penggunaan Dana Desa Tahun Anggaran 2015 Desa Batu Sawar Kec. Maro Sebo Ulu Kab. Batanghari Potensi yang dilanggar Pasal 2 jo Pasal 3 UU Nomor 31 Tahun 1999.

Dari data pada tabel 1 tersebut diketahui terdapat 2 (dua) kasus yaitu pada tahun 2015 dan 2016 dimana tindak pidana korupsi yang dilakukan berkaitan dengan Dana Desa. Dalam Pasal 41 UU Pemberantasan Tindak Pidana Korupsi dinyatakan: "Masyarakat dapat berperan serta membantu upaya pencegahan dan pemberantasan tindak pidana korupsi dengan wujud salah satunya adalah memberikan informasi adanya dugaan telah terjadinya tindak pidana korupsi. Hal ini dimaksudkan untuk meningkatkan efektivitas pencegahan dan pemberantasan tindak pidana korupsi.

Program Ipteks bagi Masyarakat yang diusulkan yaitu membekali Mitra dengan mensosialisasikan Undang-Undang Pemberantasan Tindak Pidana Korupsi dan Peraturan Daerah (Perda) Kabupaten Batanghari Tentang Pengelolaan Keuangan Desa, penyuluhan hukum tentang pemahaman isi Undang-Undang Pemberantasan Tindak Pidana Korupsi dan Peraturan Daerah (Perda) Kabupaten Batanghari Tentang Pengelolaan Keuangan Desa, simulasi hukum, mendorong mereka untuk menjadi kader anti Korupsi adalah dalam rangka menunjang Program Kerja Pemerintah Kabupaten Batanghari untuk melaksanakan Amanah Peraturan Daerah (Perda) Nomor 11 Tahun 2012 Tentang Pengelolaan Keuangan Desa.

Berdasarkan paparan yang telah dikemukakan, diperlukan peningkatan pemahaman oleh semua pihak. Dalam UU Pemberantasan Tindak Pidana Korupsi ditekankan peran serta masyarakat untuk ikut aktif memberikan pencegahan terjadinya tindak pidana korupsi dalam hal ini termasuk peran serta mitra Kepada Desa beserta perangkatnya.

Adapun permasalahan yang dapat diidentifikasi sebagai berikut:

1. Mitra belum mengetahui UU Nomor 31 Tahun 199 Tentang Pemberantasan Tindak Pidana korupsi dan Perda Kab. Batanghari Nomor 11 Tahun 2012 Tentang Pengelolaan Keuangan Desa.

2. Mitra belum memahami UU Nomor 31 Tahun 199 Tentang Pemberantasan Tindak Pidana korupsi berkaitan dengan korupsi yang merugikan keuangan negara dan Peraturan Daerah (Perda) Kabupaten Batanghari Nomor 11 Tahun 2012 Tentang Pengelolaan Keuangan Desa.

\section{Tujuan Pengabdian Pada Masyarakat}

Kegiatan pengabdian pada masyarakat ini dilakukan dengan tujuan sebagai berikut:

1. Tujuan Umum

Mensosialisasikan peraturan: (1) Undang-Undang Republik Indonesia Nomor 20

Tahun 2001 Tentang Perubahan Undang Undang Republik Indonesia Nomor 31 
Tahun 1999 Tentang Pemberantasan Tindak Pidana Korupsi; (2) Undang-Undang Republik Indonesia Nomor 31 Tahun 1999 Tentang Pemberantasan Tindak Pidana Korupsi berkaitan dengan Korupsi Yang Merugikan Keuangan Negara; (3) Peraturan Daerah Kabupaten Muaro Jambi Nomor 11 Tahun 2012 Tentang Pengelolaan Keuangan Desa.

2. Tujuan Khusus

a. Meningkatkan pengetahuan dan pemahaman Kepala Desa beserta perangkatnya Tentang Korupsi Yang Merugikan Keuangan Negara guna mencegah Tindak Pidana Korupsi pada Pemerintahan Desa.

b. Meningkatkan kemampuan mitra dalam menyampaikan ide dan pemikiran kegiatan terkait dengan pencegahan tindak pidana korupsi pada pemerintahan desa.

\section{Manfaat Pengabdian Pada Masyarakat}

Dari kegiatan pengabdian pada masyarakat ini diharapkan Kepala Desa beserta perangkatnya mendapatkan pemahaman Tentang Korupsi Merugikan Keuangan Negara, sehingga dapat mencegah Tindak Pidana Korupsi pada Pemerintahan Desa. Setelah mengetahui dan memahami apa itu korupsi merugikan keuangan negara Kepala Desa beserta perangkatnya tidak terjebak dalam perbuatan korupsi, baik karena ketidaktahuan yang bersangkutan maupun karena kesengajaan dari pelaku.

\section{TARGET DAN LUARAN}

\section{Target}

Kegiatan pengabdian pada masyarakat "Penyuluhan Hukum Tentang Merugikan Keuangan Negara Kepada Kepala Desa Se Kecamatan Pemayung Kabupaten Batang Hari Guna Pencegahan Korupsi Pada Pemerintahan Desa”. Berkaitan dengan tindak pidana korupsi siapapun dapat berpotensi untuk melakukan tindak pidana korupsi baik itu karena ketidaktahuannya, karena dengan sengaja maupun potensi untuk menyalahgunakan kewenangan, kesempatan, sarana yang ada padanya karena jabatannya. Adanya kegiatan penyuluhan ini diharapkan: (1) Meningkatnya pengetahuan mitra Kepala Desa dan Perangkat Desa Tentang "Tindak Pidana Korupsi dan Perda Kab. Batanghari No 11 Tahun 2012 Tentang Pengelolaan Keuangan Desa” (2) Meningkatkan kemampuan untuk memahami isi dari Undang-Undang Pemberantas-an Tindak Pidana Korupsi dan Perda Kab. Batanghari No. 11 Tahun 2012 Tentang Pengelolaan Keuangan Desa" Penyuluhan Hukum Tentang Merugikan Keuangan Negara Kepada Kepala Desa Se Kecamatan Pemayung Kabupaten Batang Hari Guna Pencegahan Korupsi Pada Pemerintahan Desa. Diharapkan dapat memberikan pencerahan dan upaya pencegahan kepada masyarakat khususnya para Kepala Desa dan Perangkat Desa untuk tidak terjebak karena ketidaktahuan maupun sengaja melakukan tindak pidana korupsi yang merugikan keuangan negara.

\section{Luaran}

Peningkatan Pemahaman dan Keterampilan masyarakat, dalam hal ini Mitra Mampu Menyerap Pengetahuan Tentang Tindak Pidana Korupsi dan Mitra Mampu Memahami Isi UU 
Pemberantasan Tindak Pidana korupsi \& Perda Kab. Batang-hari Tentang Pengelolaan Keuangan Desa

\section{METODE PELAKSANAAN}

Adapun metode yang dilakukan dalam kegiatan pengabdian masyarakat ini adalah dalam bentuk penyuluhan hukum yang dilakukan dengan beberapa tahapan.

1. Persiapan,

Merupakan kegiatan awal yang dilakukan dengan cara Audiensi kepada Camat Pemayung Kabupaten Batang Hari, untuk menyampaikan surat permohonan serta izin guna mengadakan penyuluhan pada Kecamatan dimaksud. Persiapan untuk menentukan lokasi kegiatan, jumlah peserta, hari dan tanggal kegiatan. Tahap berikutnya menyebarkan undangan dan konfirmasi kehadiran peserta dalam kegiatan pengabdian pada masyarakat.

2. Materi kegiatan,

- Dalam hal ini penyampaian materi tentang Tindak Pidana Korupsi Yang Berkaitan Dengan Merugikan Keuangan Negara oleh NARASUMBER. Kegiatan ini dihadiri oleh kurang lebih 50 orang peserta yang terdiri atas Kepala Desa dan Perangkat Desa se kecamatan Pemayung Kabupaten Batang Hari dengan materi sebagaimana diatur dalam Undang-Undang Nomor 31 Tahun 1999 Tentang Pemberantasan Tindak Pidana Korupsi, berkaitan dengan korupsi yang merugikan keuangan negara dan Perda Kab. Batanghari Nomor 11 Tahun 2012 Tentang Pengelolaan Keuangan Desa”. sebagai berikut: Mengadakan Penyuluhan hukum tentang isi hukum dari Undang-Undang Nomor 31 Tahun 1999 Tentang Pemberantasan Tindak Pidana Korupsi, dan Perda Kab. Batanghari Nomor 11 Tahun 2012 Tentang Pengelolaan Keuangan Desa”:

1. Korupsi Keuangan Negara, karena melawan hukum;

2. Korupsi Keuangan Negara, karena menyalahgunakan kewenangan, kesempatan atau sarana karena kedudukan dan jabatan;

3. Perda Kabupaten Batang Hari Nomor 11 Tahun 2012 Tentang Pengelolaan Keuangan Desa;

4. Hak dan kewajiban Perangkat Desa dalam pengelolaan keuangan desa.

3. Kegiatan Pokok,

1. Mengadakan Ceramah Sosialisasi Undang-Undang Nomor 31 Tahun 1999 Tentang Pemberantasan Tindak Pidana Korupsi, berkaitan dengan korupsi yang merugikan keuangan negara dan Perda Kab. Batang Hari Nomor 11 Tahun 2012 Tentang Pengelolaan Keuangan Desa".

2. Penyampaian materi dengan metode ceramah dengan materi, meliputi:

a. Korupsi Keuangan Negara, karena melawan hukum;

b. Korupsi Keuangan Negara, karena menyalahgunakan kewenangan, kesempatan atau sarana karena kedudukan dan jabatan;

c. Perda Kabupaten Batang Hari Nomor 11 Tahun 2012 Tentang Pengelolaan Keuangan Desa;

d. Hak dan kewajiban Perangkat Desa dalam pengelolaan keuangan desa. 
3. Penyampaian materi dengan memberikan contoh-contoh kasus berkaitan dengan perbuatan-perbuatan yang tergolong tindak pidana korupsi, seperti: menguntungkan orang lain, meskipun yang bersangkutan sendiri tidak mendapatkan keuntungan, tetapi melalui tanda tangannya dapat menguntungkan orang lain, maka perbuatan itu dapat digolongkan perbuatan korupsi atau tindak pidana korupsi.

4. Mengadakan Penyuluhan hukum tentang isi hukum dari Undang-Undang Nomor 31 Tahun 1999 Tentang Pemberantasan Tindak Pidana Korupsi, dan Perda Kab. Batanghari Nomor 11 Tahun 2012 Tentang Pengelolaan Keuangan Desa”:

a. Korupsi Keuangan Negara, karena melawan hukum;

b. Korupsi Keuangan Negara, karena menyalahgunakan kewenangan, kesempatan atau sarana karena kedudukan dan jabatan;

c. Perda Kabupaten Batang Hari Nomor 11 Tahun 2012 Tentang Pengelolaan Keuangan Desa;

d. Hak dan kewajiban Perangkat Desa dalam pengelolaan keuangan desa.

5. Mengadakan diskusi dan tanya jawab tentang materi yang diberikan.

\section{Evaluasi}

Evaluasi Kegiatan akan dilakukan berdasarkan hasil diskusi dan tanya jawab dengan khalayak sasaran, untuk perbaikan ke depan.

\section{Penyusunan Laporan}

Penyusunan laporan merupakan salah bentuk pertanggungjawaban tim atas kegiatan pengabdian masyarakat yang telah dilakukan.

\section{HASIL DAN PEMBAHASAN}

Kegiatan penyuluhan hukum ini dilaksanakan di Aula Kantor Camat Pemayung Kabupaten Batang Hari. Penyuluhan Hukum dihadiri oleh masyarakat terutama adalah Perangkat Desa, yaitu Kepala Desa, Sekretaris Desa, Bendahara Desa. Untuk menjamin penegakan hukum dapat dilaksanakan secara benar, adil, tidak ada kesewenang-wenangan dan tidak ada penyalahgunaan kekuasaan. Ada beberapa asas yang harus selalu tampil dalam setiap penegakan hukum, yaitu asas tidak berpihak (impartiality), asas kejujuran dalam memeriksa dan memutus (fairness), asas beracara benar (prosedural due process), asas menerapkan hukum secara benar yang menjamin dan melindungi hak-hak substantif pencari keadilan dan kepentingan sosial (lingkungan), asas jaminan bebas dari segala tekanan dan kekerasan dalam proses peradilan.

Undang-Undang Nomor 31 Tahun 1999 tentang Pemberantasan Tindak Pidana Korupsi dinilai masih mempunyai kelemahan-kelemahan dalam mengadili perkara korupsi. Oleh karena itu, pada tanggal 2 November 2001 diundangkanlah Undang-Undang Republik Indonesia Nomor 20 Tahun 2001 tentang Perubahan Atas Undang-Undang Nomor 31 Tahun 1999 tentang Pemberantasan Tindak Pidana Korupsi. Hal-hal yang diubah, adalah sebagai berikut:

1. Adanya berbagai interpretasi yang berkembang dalam masyarakat, khususnya mengenai anggapan adanya kekosongan hukum untuk memproses tindak pidana korupsi yang terjadi sebelum berlakunya Undang-Undang Nomor 31 Tahun 1999; 
2. Penerapan sistem pembuktian terbalik yakni pembuktian yang dibebankan kepada terdakwa;

3. Ketentuan perluasan mengenai sumber perolehan alat bukti yang sah yang berupa petunjuk;

4. Pembuktian terbalik ini diberlakukan pada tindak pidana baru tentang gratifikasi dan terhadap tuntutan perampasan harta benda terdakwa yang diduga berasal dari tindak pidana korupsi;

5. Pengaturan hak negara untuk mengajukan gugatan perdata terhadap harta benda terpidana yang disembunyikan atau tersembunyi dan baru diketahui setelah putusan pengadilan memperoleh kekuatan hukum tetap.

Pelaku tindak pidana korupsi yang disebut dengan kejahatan kerah putih (white collar crime) cenderung berasal dari kalangan yang mempunyai tingkat intelektual yang tinggi. Dengan kemampuan yang dimilikinya, pelaku kejahatan kerah putih akan dapat memperhitungkan secara cermat mengenai segala kemungkinan-kemungkinan yang terjadi berkaitan dengan kejahatan yang dilakukannya. Tujuan utamanya adalah untuk mengaburkan atau menutupi agar perbuatannya tidak terbongkar dan diperiksa oleh aparat penegak hukum. Akibatnya dalam pengungkapan kasus kejahatan kerah putih, aparat penegak hukum harus bekerja ekstra keras dibandingkan dengan pengungkapan kejahatan konvensional.

Aparat penegak hukum seolah-olah harus terlebih dahulu beradu kepintaran dan kecerdikan dengan pelaku kejahatan. Kondisi tersebut juga terjadi dalam pengungkapan tindak pidana korupsi, karena selain mempunyai tingkat intelektual yang tinggi, biasanya pelaku tindak pidana korupsi adalah pihak-pihak yang dekat atau bahkan memiliki kekuasaan dan kekuatan sehingga mereka dapat melakukan korupsi secara teroganisir dan tertutup.

Pada saat aparat penegak hukum bermaksud akan memulai proses penegakan hukum yang dimulai dengan tindakan penyelidikan terhadap suatu tindak pidana korupsi, maka saat itu pula pelaku korupsi akan mulai juga melakukan perlawanan terhadap upaya tersebut. Perlawanan itu dapat berupa menghilangan barang bukti, mempengaruhi para saksi, membentuk opini di masyarakat bahwa dirinya tidak bersalah.

Korupsi adalah sebagai kejahatan, pelakunya adalah penyelenggara negara dan atau pegawai negeri. Intinya adalah perbuatan yang melawan hukum atau menyalahgunakan kewenangan publik yang merugikan negara atau masyarakat. Di beberapa negara ketentuan korupsi bisa dikenakan juga kepada perseorangan atau golongan swasta (private). Bentukbentuk Korupsi yang paling umum dikenal antara lain:

1. Berkhianat, subversi, transaksi luar negeri ilegal, penyelundupan;

2. Menggelapkan barang milik lembaga,swastanisasi anggaran pemerintah, menipu dan mencuri;

3. Menggunakan uang tidak tepat, memalsu dokumen, dan menggelapkan uang, mengalirkan uang lembaga ke rekening pribadi, menggelapkan pajak dan menyalahgunakan dana;

4. Menyalahgunakan wewenang dan, intimidasi,menyiksa, penganiayaan, memberi ampun dan grasi tidak pada tempatnya; 
5. Menipu, mengecoh memberi kesan yang salah, mencurangi, memperdaya,memeras;

6. Mengabaikan keadilan, melanggar hukum, memberikan kesaksian palsu,menahan secara tidak sah, menjebak;

7. Tidak menjalankan tugas, desersi, hidup menempel pada orang lain seperti benalu;

8. Penyuapan dan penyogokan,memeras, mengutip pungutan, meminta komisi;

9. Menjegal Pemilihan Umum, memalsu kertas suara, membagi-bagi wilayah Pemilu agar bisa unggul;

10. Menggunakan informasi internal dan informasi rahasiah untuk kepentingan pribadi, membuat laporan palsu;

11. Menjual tanpa izin Jabatan pemerintah,barang milik pemerintah, dan surat izin pemerintah;

12. Manipulasi peraturan,pembelian barang-barang persediaan, kontrak dan pinjaman uang;

13. Menghindari pajak meraih laba berlebih-lebihan;

14. Menjual pengaruh, menawarkan jasa perantara, konflik kepentingan;

15. Menerima hadiah, uang jasa, uang pelicin dan hiburan, perjalanan yang tidak pada tempatnya;

16. Berhubungan dengan organisasi kejahatan,operasi pasar gelap;

17. Perkoncoan menutupi kejahatan;

18. Memata-matai secara tidak sah, menyalahgunakan telekomunikasi dan pos, dan;

19. Menyalahgunakan stempel dan kertas surat kantor, rumah jabatan dan hak istimewa jabatan.

Untuk menjatuhkan pidana terhadap pelaku tindak pidana korupsi bukanlah hal yang mudah. Dipidananya seseorang tidaklah cukup apabila orang itu telah melakukan perbuatan yang bertentangan dengan hukum atau bersifat melawan hukum. Jadi meskipun perbuatannya memenuhi rumusan delik dalam undang-undang dan tidak dibenarkan, hal tersebut belum memenuhi syarat untuk penjatuhan pidana. Untuk pemidanaan masih perlu adanya syarat, yaitu bahwa orang yang melakukan perbuatan itu mempunyai kesalahan atau bersalah (subjective guilt). Syarat-syarat yang harus dipenuhi dalam hal dapat dihukumnya suatu perbuatan pidana, yaitu harus terpenuhinya unsur-unsur tindak pidana itu sendiri. Unsur-unsur tindak pidana ini terbagi atas dua macam yaitu unsur subjektif dan unsur objektif.

Kesalahan, Pertanggungan jawab dan Pidana adalah ungkapan-ungkapan yang terdengar dan digunakan dalam pencakapan sehari-hari dalam moral, agama, dan hukum. Tiga unsur itu berkaitan satu dengan yang lain, dan berakar dalam satu keadaan yang sama, yaitu adanya pelanggaran terhadap suatu sistem aturan-aturan. Di sini berlaku apa yang disebut asas "Tiada Pidana Tanpa Kesalahan" (Keine Strafe ohne Schuld atau Geen straf zonder schuld atau Nulla Poena Sine Culpa ("culpa" di sini dalam arti luas, meliputi juga kesengajaan). "Asas tiada pidana tanpa kesalahan (geen straf zonder schuld) merupakan suatu penyaring bahwa hanya mereka yang mempunyai kesalahan saja yang patut dipidana" (Utrecht, 1986: 288-289).

Seseorang telah melakukan perbuatan yang melawan hukum, tidak serta merta membuatnya dapat dijatuhi pidana. Hanya apabila ia dapat dipersalahkan, barulah yang 
bersangkutan dapat dipertanggungjawabkan atas perbuatannya itu. Asas ini tidak tercantum dalam KUHP Indonesia atau dalam peraturan lain. Berlakunya asas tersebut sekarang tidak diragukan akan bertentangan dengan rasa keadilan, apabila ada orang yang dijatuhi pidana padahal ia sama sekali tidak bersalah. Untuk adanya pemidanaan harus ada kesalahan harus ada kesalahan pada si pembuat. Asas "tiada pidana tanpa kesalahan" yang telah disebutkan tersebut mempunyai sejarahnya sendiri. Akan tetapi justru harus adanya unsur kesalahan inilah membuat penegak hukum harus bekerja maksimal, karena sangatlah sulit mengetahui Mens rea (niat) jahat pelaku tindak pidana korupsi tersebut.

Untuk sampai pada kesimpulan bahwa seorang pelaku dapat dipertanggungjawabkan menurut hukum pidana, hakim harus menilai beberapa hal. Pertama-tama ia harus menentukan bahwa pelaku perbuatan melawan hukum itu adalah orang yang normal mampu untuk bertanggungjawab; selanjutnya membuktikan pelaku melakukan perbuatan itu dengan kesalahan (berupa kesengajaan atau kealpaan) dan yang terakhir, pelaku tidak memiliki dasar penghapus kesalahan. (Moeljatno, 1983).

Memperhatikan uraian tersebut di atas terlihat betapa tidak mudahnya untuk menjatuhkan pidana kepada seseorang atas perbuatan pidana yang telah dilakukannya sendiri.

Hukum pidana Indonesia menganut asas kesalahan yang merupakan dasar untuk menerapkan pertanggung jawaban pidana kepada pelaku yang melanggar ketentuan hukum pidana. artinya untuk dapat memidana pelaku delik, selain membuktikan unsur-unsur perbuatan yang menimbulkan celaan, dalam diri pelaku harus ada unsur kesalahan. Kesalahan merupakan keadaan jiwa dari si pembuat dan hubungan batin antara si pembuat dengan perbuatannya, keadaan jiwa dari seseorang yang melakukan perbuatan merupakan apa yang lazim disebut sebagai kemampuan bertanggung jawab, sedang hubungan batin antar si pembuat dengan perbuatanya itu merupakan kesengajaan, kealpaan serta pemaaf (Muladi dan Dwidja Priyatno, 1991).

Untuk menentukan adanya kesalahan sebagai dasar dari pertanggungjawaban pidana harus memenuhi unsur-unsur sebagai berikut:

1. Adanya kemampuan bertanggungjawab pada si pembuat. Menurut para ahli sarjana bahwa untuk adanya kemampuan bertanggung jawab harus ada:

a) Kemampuan untuk membeda-bedakan antara perbuatan yang baik dan buruk: yang sesuai hukum dan yang melawan hukum;

b) Kemampuan untuk menentukan kehendaknya menurut keinsyafan tentang baik buruknya perbuatan tadi;

2. Hubungan antara batin pelaku dengan perbuatannya yang berupa kesengajaan (Dolus), atau kealpaan (Culpa) ini disebut bentuk-bentuk kesalahan;

3. Tidak adanya alasan penghapus kesalahan atau tidak ada alasan pemaaf Pasal 44 KUHP berbunyi "Barangsiapa melakukan perbuatan yang tidak dapat dipertanggung jawabkan padanya, disebabkan jiwanya cacat dalam tubuhnya atau tergangu karena penyakit tidak dipidana”. Menurut pasal tersebut maka hal tidak mampu bertanggung jawab adalah karena hal-hal tertentu, yaitu jiwa yang cacat 
dalam pertumbuhannya atau terganggu karena penyakit, dan sebagai akibatnya ia tidak mampu mempertanggung jawabkan perbuatannya, (Moeljatno, 1983).

Dengan terpenuhi semua unsur di atas, maka seseorang dapat dijatuhi suatu sanksi pidana yang telah ditentukan oleh peraturan perundang-undangan. Lain halnya perbuatan pidana dilakukan oleh korporasi atau badan hukum yang tanpa spesifikasi yang jelas atau identitas yang jelas,maka masalah kesulitan siapa pembuatnya akan selalu timbul, dan hal ini akan membawa konsekuensi tentang masalah pertanggungjawaban pidana secara kolektif, walaupun telah terpenuhinya semua unsur untuk dapat dipidana.

a. Hasil Monitoring dan Evaluasi

Kegiatan monitoring dan evaluasi dilakukan secara bersamaan selama kegiatan penyuluhan berlangsung. Instrumen yang digunakan meliputi pengamatan secara langsung mengenai sikap dan melalui daftar pertanyaan atau kuis yang diberikan langsung oleh Tim Penyuluhan. Hasil kegiatan monitoring dan evaluasi dapat dilihat pada Tabel 2 berikut:

Tabel 2. Hasil Kegiatan Monitoring dan Evaluasi

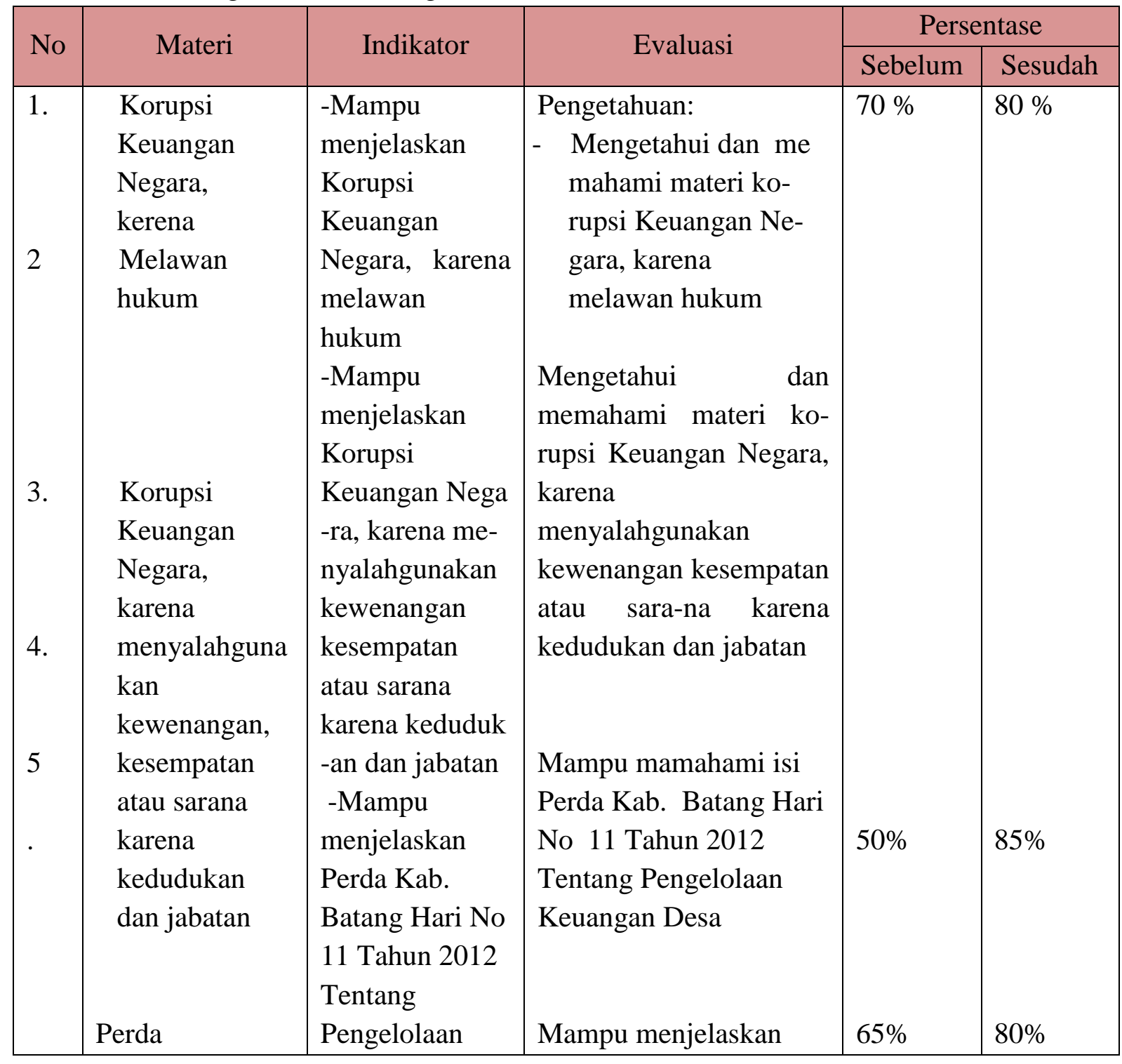




\begin{tabular}{|c|c|c|}
\hline $\begin{array}{l}\text { Kabupaten } \\
\text { Batang Hari } \\
\text { Nomor } 11 \\
\text { Tahun } 2012 \\
\text { Tentang } \\
\text { Pengelolaan } \\
\text { Keuangan Desa } \\
\text { Hak dan } \\
\text { kewajiban } \\
\text { Perangkat Desa } \\
\text { Evaluasi }\end{array}$ & $\begin{array}{l}\text { Keuangan Desa } \\
\text {-Mampu menje- } \\
\text { laskan Hak dan } \\
\text { Kewajiban } \\
\text { Perangkat Desa } \\
\text { - Mampu } \\
\text { menyampaikan } \\
\text { Pemikiran, ide } \\
\text { berkaitan } \\
\text { dengan } \\
\text { pencegahan } \\
\text { korupsi pada } \\
\text { perangkat Desa. }\end{array}$ & $\begin{array}{l}\text { Hak dan Kewajiban } \\
\text { Perangkat Desa } \\
\text { Sikap: } \\
\text { Mengajukan beberapa } \\
\text { pertanyaan yang } \\
\text { relevan dengan materi } \\
\text { Mengikuti kegiatan } \\
\text { sampai dengan selesai } \\
\text { Tertib dan disiplin } \\
\text { berpartisi- pasi secara } \\
\text { aktif. } \\
\text { Peserta mampu } \\
\text { menyampaikan ide } \\
\text { kegiatan berkaitan } \\
\text { dengan pencegahan } \\
\text { korupsi pada } \\
\text { perangkat Desa. }\end{array}$ \\
\hline
\end{tabular}

Berdasarkan hasil evaluasi yang dilakukan melalui kuis sebelum maupun setelah kegiatan dilaksanakan serta pengamatan selama kegiatan penyuluhan maka diperoleh hasil sebagai berikut:

1. $80 \%$ peserta penyuluhan mengetahui dan memahami materi tentang korupsi Keuangan Negara, karena melawan hukum dan menyalahgunakan kewenangan kesempatan atau sarana karena kedudukan dan jabatan yang ada padanya; dan Perda Kabupaten Batang Hari Nomor 11 Tahun 2012 Tentang Pengelolaan Keuangan Desa. Mengetahui dan memahami Hak dan Kewajiban Perangkat Desa.

2. $85 \%$ peserta penyuluhan berpartisipasi secara aktif selama kegiatan berlangsung dengan ditandai pertanyaan-pertanyaan yang diajukan sesuai dengan materi penyuluhan serta menunjukkan kedisiplinan dan tata tertib selama mengikuti kegiatan.

3. $80 \%$ peserta penyuluhan mampu menyampaikan ide pemikiran berkaitan dengan pencegahan korupsi pada perangkat Desa.

4. Selama kegiatan penyuluhan, peserta menunjukkan sikap antusias dengan ditandai banyaknya pertanyaan yang diajukan oleh para peserta kepada Narasumber/instruktur.

\section{KESIMPULAN DAN SARAN}

\section{Kesimpulan}

Akseptabilitas berupa tingkat penyerapan mitra terhadap kegiatan mengalami peningkatan yang diukur dari tingkat pengetahuan dan pemahaman tentang materi kegiatan. Adanya peningkatan pengetahuan dan pemahaman peserta tentang isi Undang - Undang Nomor 31 
Tahun 1999 jo UU No 20 Tahun 2001 Tentang Pemberantasan Tindak Pidana Korupsi, UU Nomor 6 Tahun 2014 Tentang Desa, Permendagri Nomor 113 tahun 2014 Tentang Pedoman Pengelolaan Keuangan Desa, Peraturan Daerah Nomor 11 Tahun 2012 Tentang Pengelolaan Keuangan Desa. serta mampu menyampaikan ide atau pemikiran berkaitan dengan Pencegahan secara dini tindak pidana korupsi di kalangan Perangkat Desa.

\section{Saran}

Kegiatan penyuluhan sangat bermanfaat bagi masyarakat, khususnya Perangkat Desa tentang masalah korupsi. Kegiatan penyuluhan dapat dilakukan secara berkelanjutan dan terencana.

\section{DAFTAR PUSTAKA}

Harkrisnowo, Harkristuti. 2002. "Korupsi, Konspirasi dan keadilan di Indonesia", Jurnal Dictum LeIP, Edisi I, Lentera Hati, Jakarta.

Hartati, Evi. 2005. Tindak Pidana Korupsi, Penerbit Sinar Grafika, Jakarta.

Kristian \& Yopi Gunawan. 2015. Tindak Pidana Korupsi, Refika Aditama, Bandung,

Komisi Pemberantasan Korupsi, 2006. Memahami untuk Membasmi Korupsi, diterbitkan oleh Komisi pemberantasan korupsi, Jakarta.

Lubis, Mochtar \& James C. Scott. 1995. Bunga Rampai Korupsi, LP3ES, Jakarta.

Moeljatno. 1987. Asas-Asas Hukum Pidana. Bina Aksara. Jakarta.

Moeljatno. 1983. Perbuatan Pidana dan Pertanggung Jawaban dalam Hukum Pidana, Bina Aksara, Yogyakarta.

Muladi dan Dwidja Priyatno. 1991. Pertanggungjawaban Korporasi Dalam Hukum Pidana. Sekolah Tinggi Bandung. Bandung.

Wijoyanto, Bambang. 2007. Harmonisasi Penegakan Hukum Dalam Pemberantasan Korupsi, Jurnal Legislasi Indonesia, Volume 4 Nomor 1, Dirjen Perundang-undangan Depkum dan HAM RI.

Waluyadi. 1999. Pengetahuan Dasar Hukum Acara Pidana (Sebuah Catatan Khusus). Mandar Maju. Bandung.

Utrecht, Hukum Pidana 1, Pustaka Tinta Mas, Surabaya, 1986, hal. 288-289.

Undang-Undang Republik Indonesia Nomor 20 Tahun 2001 Tentang Perubahan Undang Undang Republik Indonesia Nomor 31 Tahun 1999 Tentang Pemberantasan Tindak Pidana Korupsi.

Undang-Undang Republik Indonesia Nomor 31 Tahun 1999 Tentang Pemberantasan Tindak Pidana Korupsi.

Peraturan Daerah Kabupaten Muaro Jambi Nomor 11 Tahun 2012 Tentang Pengelolaan Keuangan Desa. 